\title{
Overview of Strategies for High-Temperature Creep and Oxidation Resistance of Alumina-Forming Austenitic Stainless Steels
}

\author{
Y. YAMAMOTO, M.P. BRADY, M.L. SANTELLA, H. BEI, P.J. MAZIASZ, and B.A. PINT
}

A family of creep-resistant, alumina-forming austenitic (AFA) stainless steel alloys is under development for structural use in fossil energy conversion and combustion system applications. The AFA alloys developed to date exhibit comparable creep-rupture lives to state-of-the-art advanced austenitic alloys, and superior oxidation resistance in the $\sim 923 \mathrm{~K}$ to $1173 \mathrm{~K}\left(650{ }^{\circ} \mathrm{C}\right.$ to $900{ }^{\circ} \mathrm{C}$ ) temperature range due to the formation of a protective $\mathrm{Al}_{2} \mathrm{O}_{3}$ scale rather than the $\mathrm{Cr}_{2} \mathrm{O}_{3}$ scales that form on conventional stainless steel alloys. This article overviews the alloy design approaches used to obtain high-temperature creep strength in AFA alloys via considerations of phase equilibrium from thermodynamic calculations as well as microstructure characterization. Strengthening precipitates under evaluation include MC-type carbides or intermetallic phases such as $\mathrm{NiAl}-\mathrm{B} 2, \mathrm{Fe}_{2}(\mathrm{Mo}, \mathrm{Nb})$-Laves, $\mathrm{Ni}_{3} \mathrm{Al}-\mathrm{L} 1_{2}$, etc. in the austenitic single-phase matrix. Creep, tensile, and oxidation properties of the AFA alloys are discussed relative to compositional and microstructural factors.

DOI: $10.1007 / \mathrm{s} 11661-010-0295-2$

(C) The Minerals, Metals \& Materials Society and ASM International 2010

\section{INTRODUCTION}

THE efficiency of fossil-fired boiler/steam turbine power plants can be increased by increasing the operation temperature and pressure, with a further benefit of reduced greenhouse gas emissions. ${ }^{[1,2]}$ Candidate structural materials of interest to achieve temperature/ pressure increases range, depending on component, from ferritic and austenitic stainless steels to Ni base alloys. Extensive efforts are underway worldwide to evaluate and further improve high-temperature strength, oxidation/corrosion resistance, and fabricability in these classes of materials, ideally at reduced or equivalent cost to currently used materials. ${ }^{[3,4]}$

A family of alumina-forming austenitic (AFA) stainless steel alloys is currently under development by the authors. ${ }^{[5-15]}$ These alloys are targeted for potential use as superheater/reheater tubes in fossil-fired steam plants, among other applications for chemical and petrochemical processing and energy production. The AFA alloys possess the ability to form an external, protective $\mathrm{Al}_{2} \mathrm{O}_{3}$ scale at $873 \mathrm{~K}$ to $1173 \mathrm{~K}\left(600{ }^{\circ} \mathrm{C}\right.$ to $\left.900{ }^{\circ} \mathrm{C}\right)$, which affords superior oxidation and corrosion protection to the $\mathrm{Cr}_{2} \mathrm{O}_{3}$ scales that grow on conventional stainless steel alloys in many industrially relevant environments.

Y. YAMAMOTO, Research and Development Associate, M.P. BRADY and M.L. SANTELLA, Senior Research and Development Staff Members, H. BEI, Research and Development Staff Member, P.J. MAZIASZ, Distinguished Research and Development Staff Member, and B.A. PINT, Group Leader, are with the Materials Science and Technology Division, Oak Ridge National Laboratory, Oak

Ridge, TN 37831-6083. Contact e-mail: yamamotoy@ornl.gov

Author's Note: Part of this overview article is based on an earlier review (Ref. 5 and findings first reported in Refs. 6-15).

Manuscript submitted January 4, 2010.

Article published online July 3, 2010
Of particular interest to fossil-fired steam plant applications is the potential for superior oxidation resistance to water vapor/steam containing environments. ${ }^{[16-18]}$ High-temperature creep strength is achieved in AFA alloys primarily via MC carbide precipitates. The alloys typically contain only 2.5 to 4 wt pet $\mathrm{Al}$ and less than $15 \mathrm{wt}$ pct $\mathrm{Cr}$ in order to permit stabilization of an austenitic matrix for high-temperature strength at relatively low levels of $\mathrm{Ni}$ additions (20 to $25 \mathrm{wt}$ pct).

Development efforts for AFA alloys date back to at least the 1970s based on the recognition that alumina scales offer the potential for superior oxidation/corrosion resistance to chromia scales in many environments. ${ }^{[19-22]}$ However, none have succeeded sufficiently in developing compositions that exhibit both creep and oxidation resistance. This is because of the strong bcc stabilizing effect of $\mathrm{Al}$ and $\mathrm{Cr}$ additions on $\mathrm{Fe},{ }^{[23]}$ which makes the materials unacceptably weak at elevated temperatures if a single-phase austenitic matrix cannot be obtained. Due to these complications, many efforts have instead focused on alumina coatings or aluminizing surface treatments for austenitic stainless steel alloys (e.g., References 24 through 26). The need for coatings increases component cost, brings into play durability and compatibility issues with the substrate alloys, and may not be feasible for some component applications.

The key to the recent AFA alloy development effort by the authors is the discovery that a protective alumina scale can be formed at $923 \mathrm{~K}$ to $1073 \mathrm{~K}\left(650{ }^{\circ} \mathrm{C}\right.$ to $800^{\circ} \mathrm{C}$ ) with as little as $2.5 \mathrm{wt}$ pct $\mathrm{Al}$, if $\mathrm{Ti}$, $\mathrm{V}$, and $\mathrm{N}$ additions were minimized and relatively high levels of $\mathrm{Nb}$ additions were employed ( $>0.6$ to $1 \mathrm{wt}$ pct $\mathrm{Nb}) \cdot{ }^{[6,8,14]} \mathrm{A}$ unique behavior of the AFA alloys is that all compositions exhibit a transition from protective alumina scale formation to internal oxidation of $\mathrm{Al}$ with 
increasing temperature from $1073 \mathrm{~K}$ to $1273 \mathrm{~K}\left(800{ }^{\circ} \mathrm{C}\right.$ to $1000{ }^{\circ} \mathrm{C}$ ), depending on composition and oxidizing environment. ${ }^{[14]}$ This behavior is a consequence of composition choices needed to balance alumina scale formation with mechanical properties, particularly creep resistance. This article reviews the AFA developmental efforts to date, and focuses on discussion of the key alloy design considerations needed to obtain both creep and oxidation resistance at elevated temperatures.

\section{CONSIDERATION OF PHASE EQUILIBRIUM}

\section{A. Need for a Single-Phase Austenitic Matrix}

The formation of $\delta$-Fe and $\sigma-\mathrm{FeCr}$ phases in AFA alloys significantly degrades their high-temperature strength. ${ }^{[7]}$ Figure 1 illustrates superimposed isothermal sections of the Fe-Cr-Ni ternary phase diagram at $1473 \mathrm{~K}$ $\left(1200{ }^{\circ} \mathrm{C}\right.$, bold lines) and $1073 \mathrm{~K}\left(800{ }^{\circ} \mathrm{C}\right.$, broken lines), which corresponds to a solution heat-treatment temperature and an expected service temperature of the AFA alloys, respectively. ${ }^{[7,27]}$ Previous studies revealed that at least $2.5 \mathrm{wt}$ pct of the $\mathrm{Al}$ addition would be required to obtain $\mathrm{Al}_{2} \mathrm{O}_{3}$ scale formability at elevated temperatures. ${ }^{[6]}$ The addition of $\mathrm{Al}$ at this level is sufficient to significantly modify phase equilibrium. The phase boundaries between the $\gamma$-Fe single-phase and the two-phase co-existing regions with $\delta$-Fe or $\sigma$-FeCr shift toward lower $\mathrm{Cr}$ content by the $\mathrm{Al}$ addition, as indicated by arrows in Figure 1, because of strong $\delta$-Fe $/ \sigma-\mathrm{FeCr}$ stabilization effect of the $\mathrm{Al}$ addition relative to $\gamma$-Fe. ${ }^{[23]}$ It should be noted that the higher levels of $\mathrm{Cr}$ addition would favor protective alumina scale formation, because the addition of $\mathrm{Cr}$ can significantly lower the amount of Al required to form protective $\mathrm{Al}_{2} \mathrm{O}_{3}$ scales at elevated temperatures, the so-called third-element effect. ${ }^{[28]}$ A recent study also revealed that higher $\mathrm{Cr}$ content in

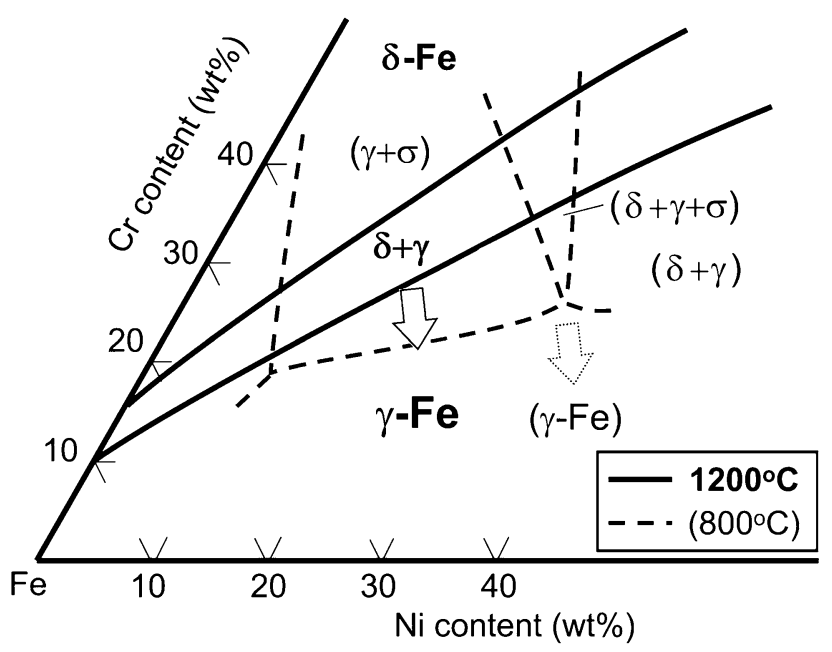

Fig. 1-Superimposed ternary phase diagram of Fe-Cr-Ni near the Fe-rich corner at $1473 \mathrm{~K}\left(1200{ }^{\circ} \mathrm{C}\right.$, bold lines $)$ and at $1073 \mathrm{~K}$ $\left(800{ }^{\circ} \mathrm{C}\right.$, broken lines). Arrows indicate the direction of phase boundaries shifting by the $\mathrm{Al}$ addition due to the strong $\delta$-Fe stabilizing effect of $\mathrm{Al}$ relative to $\gamma$-Fe. ${ }^{[7]}$ the austenitic matrix phase helped to favor external $\mathrm{Al}_{2} \mathrm{O}_{3}$ scale formation at elevated temperatures in AFA alloys, especially in water-vapor containing environments. ${ }^{[14]}$ Therefore, it is important to identify the Cr solution limit in the $\gamma$-Fe matrix at a given amount of Al addition, together with further alloying additions such as $\mathrm{Mo}, \mathrm{Nb}$, and $\mathrm{C}$, which are beneficial elements for high-temperature strengthening. ${ }^{[7,12]}$

Computational thermodynamic calculations revealed that $\sigma-\mathrm{FeCr}$ formation is the more restrictive factor, rather than $\delta$-Fe formation, to define the AFA alloy composition range. Figure 2 shows the upper limits of $\mathrm{Cr}$ and $\mathrm{Al}$ additions to avoid $\delta$-Fe phase formation in a temperature range from $873 \mathrm{~K}$ to $1473 \mathrm{~K}\left(600{ }^{\circ} \mathrm{C}\right.$ to $1200{ }^{\circ} \mathrm{C}$ ) (Figure 2(a)) and $\sigma-\mathrm{FeCr}$ phase formation at

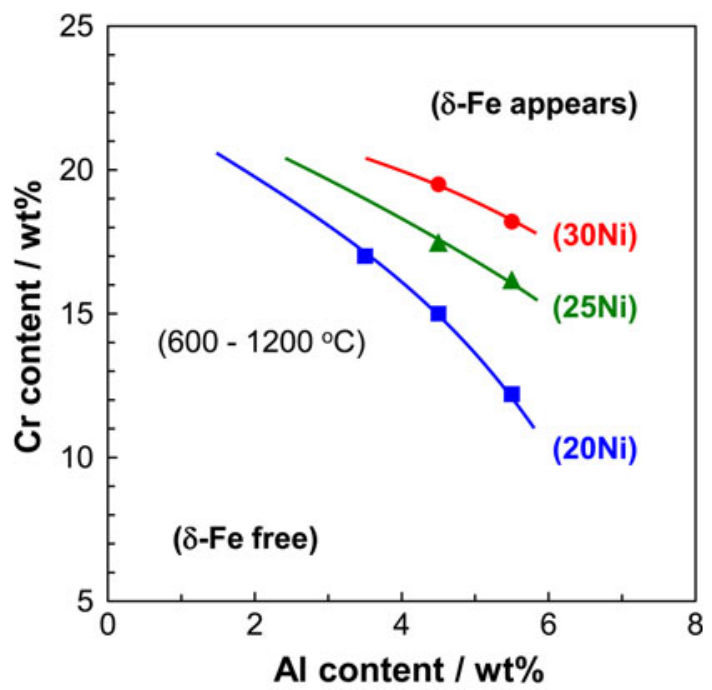

(a)

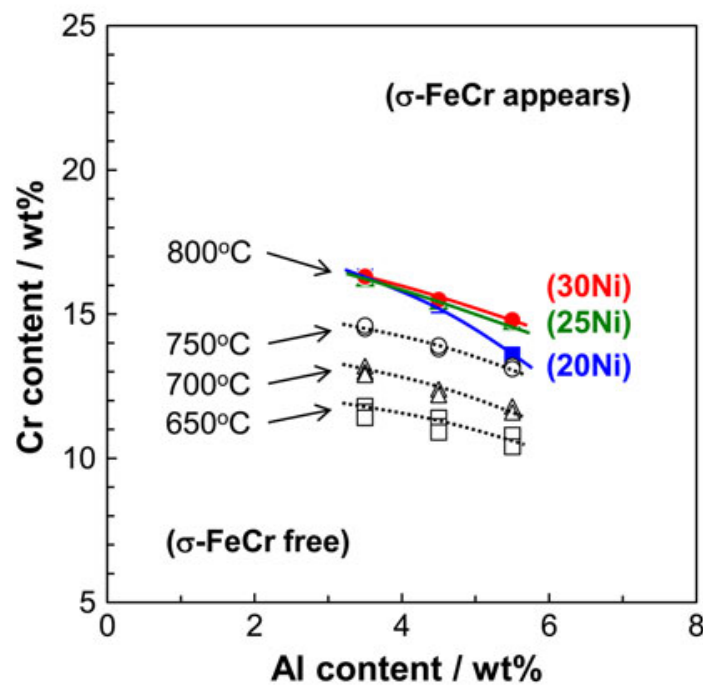

(b)

Fig. 2-Phase diagram of Fe-Cr-Al-(20, 25, 30)Ni-1Nb-2Mo-0.1C showing limitations of $\mathrm{Cr}$ and $\mathrm{Al}$ additions to avoid the formation of $\delta$-Fe $\left((a)\right.$ in a range of $873 \mathrm{~K}$ to $1473 \mathrm{~K}\left(600{ }^{\circ} \mathrm{C}\right.$ to $\left.\left.1200{ }^{\circ} \mathrm{C}\right)\right)$ and $\sigma$ - $\mathrm{FeCr}$ (b) at $923 \mathrm{~K}, 973 \mathrm{~K}, 1023 \mathrm{~K}$, and $1073 \mathrm{~K}\left(650{ }^{\circ} \mathrm{C}, 700{ }^{\circ} \mathrm{C}, 750{ }^{\circ} \mathrm{C}\right.$, and $\left.800^{\circ} \mathrm{C}\right)$ ) phases, predicted by a thermodynamic calculation. ${ }^{[12]}$ 
$923 \mathrm{~K}, 973 \mathrm{~K}, 1023 \mathrm{~K}$, and $1073 \mathrm{~K}\left(650{ }^{\circ} \mathrm{C}, 700{ }^{\circ} \mathrm{C}\right.$, $750{ }^{\circ} \mathrm{C}$, and $800{ }^{\circ} \mathrm{C}$ ) (Figure 2(b)), based on thermodynamic calculations of Fe-Cr-Al- $(20,25,30) \mathrm{Ni}-1 \mathrm{Nb}-2 \mathrm{Mo}-$ $0.1 \mathrm{C}$ (wt pct) alloys. ${ }^{[12]}$ The upper limit of $\mathrm{Cr}$ to avoid $\delta$-Fe formation decreases with increasing $\mathrm{Al}$ additions, although the limits increase significantly with increasing $\mathrm{Ni}$ additions because of the strong fcc stabilizing effect of $\mathrm{Ni}$. On the other hand, the $\mathrm{Cr}$ upper limits for $\sigma-\mathrm{FeCr}$ free region are insensitive to the amount of $\mathrm{Ni}$ addition at the designated temperatures, especially below $1023 \mathrm{~K}$ $\left(750{ }^{\circ} \mathrm{C}\right)$. The $\mathrm{Cr}$ limits decrease with decreasing temperatures, and most of the $\sigma-\mathrm{FeCr}$ free regions below $1023 \mathrm{~K}\left(750{ }^{\circ} \mathrm{C}\right)$ become smaller than the $\delta$-Fe free regions with $20 \mathrm{wt}$ pct $\mathrm{Ni}$. These results suggest that the AFA alloy compositions have to be selected relative to the intended application temperature range to be used. For the higher temperature use, such as above $1073 \mathrm{~K}$ $\left(800{ }^{\circ} \mathrm{C}\right), \sim 15$ wt pet $\mathrm{Cr}$ with 3 to $5 \mathrm{wt}$ pet $\mathrm{Al}$ can be used to avoid $\sigma-\mathrm{FeCr}$ formation, and more than $25 \mathrm{wt}$ pet $\mathrm{Ni}$ would be required to eliminate $\delta$-Fe formation. At temperatures around $923 \mathrm{~K}\left(650{ }^{\circ} \mathrm{C}\right)$, the amount of the $\mathrm{Cr}$ addition would be limited to around $12 \mathrm{wt}$ pet or less for 3 to $5 \mathrm{wt}$ pet Al containing alloys to remain $\sigma-\mathrm{FeCr}$ free. Additional thermodynamic calculations also predicted that the composition ranges free from the $\delta$-Fe and $\sigma$-FeCr formation can be expanded by using proper alloying additions, i.e. increasing $\mathrm{C}$ or $\mathrm{Cu}$ and reducing $\mathrm{Mo}$ or $\mathrm{W}$, respectively. Note that higher levels of $\mathrm{Ni}$ additions would be preferred for better oxidation resistance, ${ }^{[11]}$ but also increase the raw material cost because of the high price of $\mathrm{Ni}^{[29]}$
The AFA alloy compositions must be selected based on achieving a balance of these considerations.

\section{B. Second-Phase Precipitation}

Table I summarizes the effects of alloying additions on properties of the AFA alloys developed to date. It describes the advantages and disadvantages of various key alloying additions as a function of concentration (qualitatively low to high), based on insights obtained from the AFA alloy development effort as well as wellknown trends from conventional austenitic stainless steel alloys. ${ }^{[5-15,23]}$ As with conventional stainless steel alloys, optimization of composition for AFA alloys reflects competing and often contradictory effects of the various alloying additions on oxidation resistance, hightemperature mechanical properties, workability, and raw material cost.

Multiple precipitate phases are observed in AFA alloys over the target service range of $873 \mathrm{~K}$ to $1173 \mathrm{~K}$ $\left(600{ }^{\circ} \mathrm{C}\right.$ to $\left.900{ }^{\circ} \mathrm{C}\right)$, primarily $\mathrm{MC}(\mathrm{M}$ : mainly $\mathrm{Nb})$, $\mathrm{M}_{23} \mathrm{C}_{6}$ (M: mainly $\mathrm{Cr}$ ), NiAl-type B2, and $\mathrm{Fe}_{2}(\mathrm{Mo}, \mathrm{Nb})-$ type Lave phase, as well as minor amounts of boride and phosphide phase precipitates. ${ }^{[7,12]}$ The amounts of these second phases strongly depend on the alloy compositions, especially $\mathrm{Al}$ and $\mathrm{Nb}$, as shown in Figure 3. The bar graphs represent the volume fraction of the second phases in the AFA alloys based on Fe-20Ni-(12-14)Cr(2.5-4)Al-(0.2-3.3) Nb-0.1C with small alloying additions of $\mathrm{Mn}, \mathrm{Si}, \mathrm{Cu}, \mathrm{Mo}, \mathrm{W}, \mathrm{B}$, and $\mathrm{P}$, at $1473 \mathrm{~K}\left(1200{ }^{\circ} \mathrm{C}\right)$ (Figure 3(a)) and $1023 \mathrm{~K}\left(750^{\circ} \mathrm{C}\right)$ (Figure 3(b)), which

Table I. Effects of Alloying Additions on the Properties of AFA Stainless Steel Alloys

Key Alloying

Elements $\quad$ Effect of Alloying Addition (Amount: Low $\rightarrow$ High)

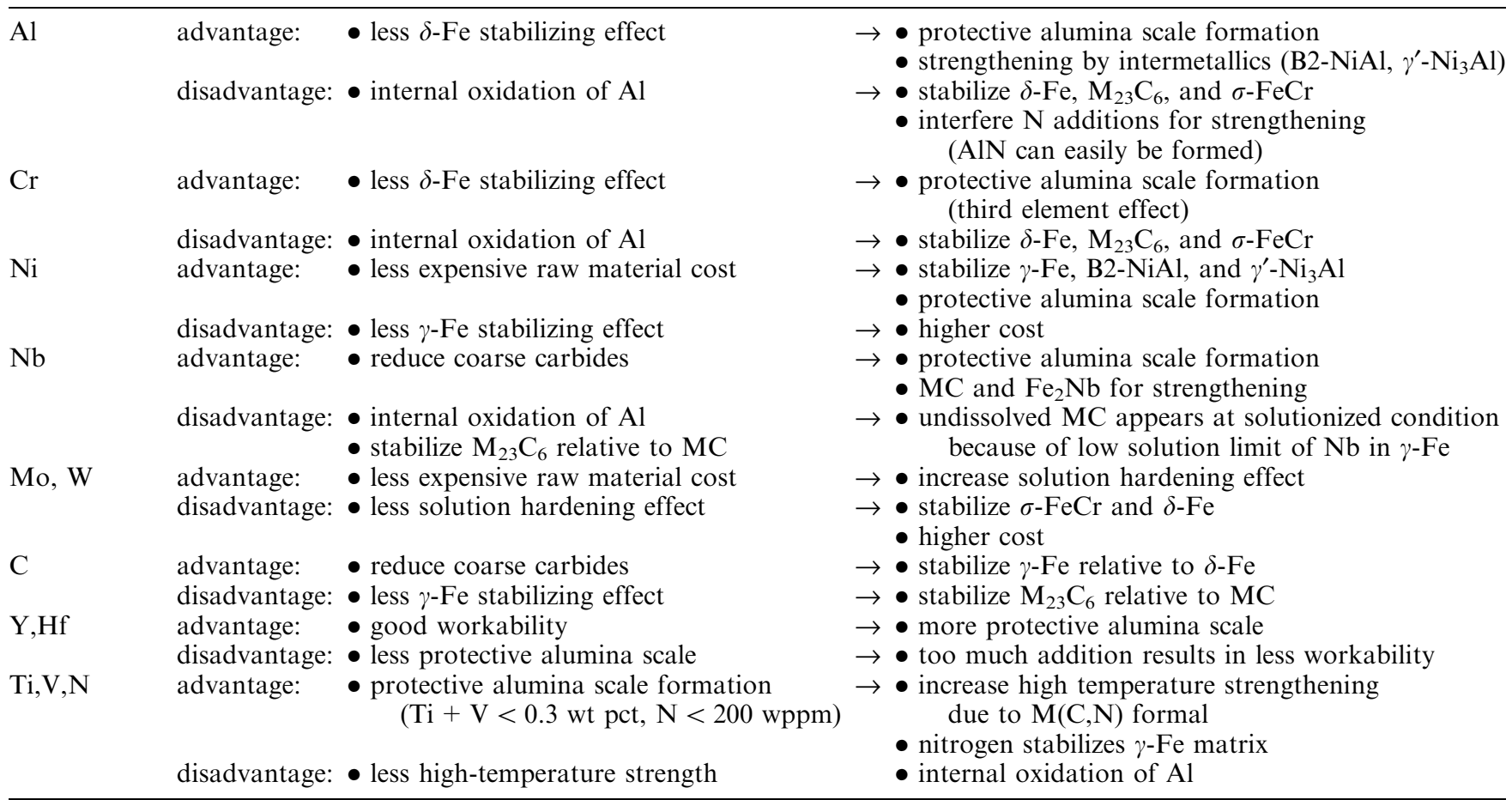




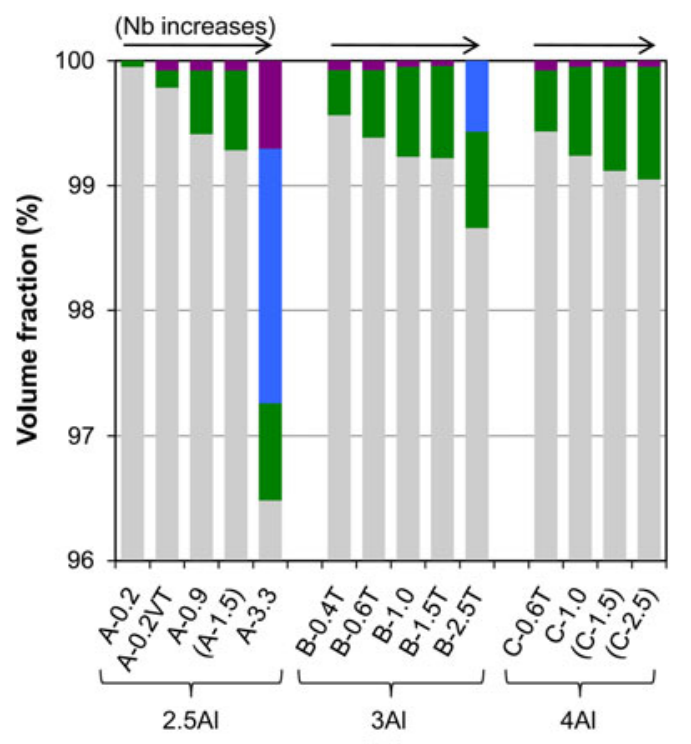

(a)

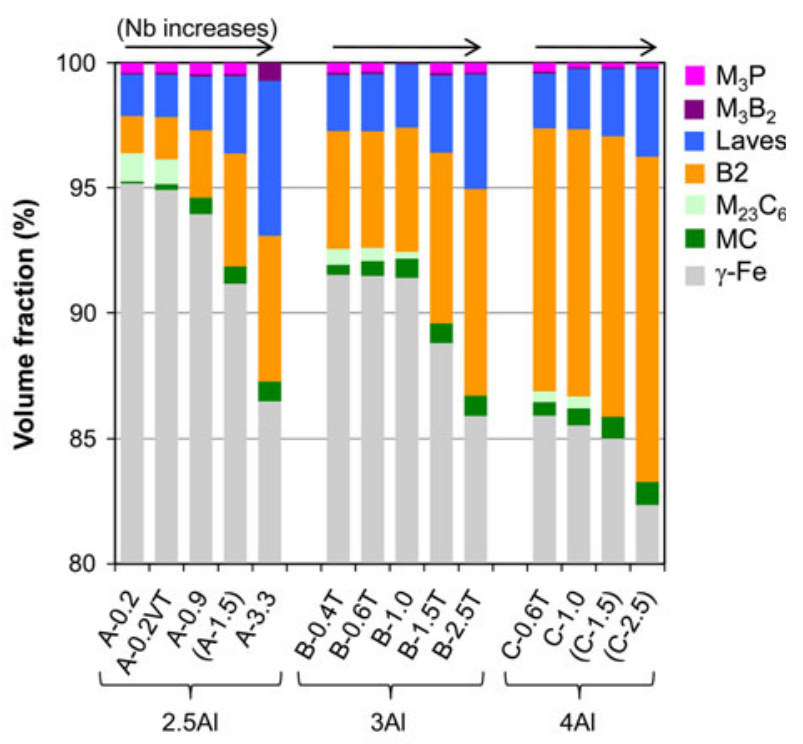

(b)

Fig. 3-Calculated volume fraction of the equilibrated phases in the alloys based on Fe-(12-14)Cr-(2.5-4)Al-20Ni-(0.2-3.3)Nb-0.1C with small alloying additions of $\mathrm{Mo}, \mathrm{Si}, \mathrm{Mn}, \mathrm{Ti}, \mathrm{P}$, and $\mathrm{B}:(a)$ at $1473 \mathrm{~K}\left(1200^{\circ} \mathrm{C}\right)$ and $(b)$ at $1023 \mathrm{~K}\left(750{ }^{\circ} \mathrm{C}\right) \cdot{ }^{[12]}$ Note that "A, B, and C" in the alloy names correspond to the amounts of $\mathrm{Al}$ additions with " $2.5,3$, and $4 \mathrm{wt}$ pct," respectively. The numbers in the alloy names represent the amount of $\mathrm{Nb}$ additions in weight percent. Note that the higher amount of $\mathrm{M}_{3} \mathrm{~B}_{2}$ in $\mathrm{A}-3.3$ is due to this alloy's higher overall $\mathrm{B}$ content.

were predicted by a computational thermodynamic calculation. The detailed alloy compositions as well as the calculation method were described elsewhere. ${ }^{[12]} \mathrm{MC}$ is the dominant second phase at $1473 \mathrm{~K}\left(1200^{\circ} \mathrm{C}\right)$, which is a typical solution heat-treatment temperature for the AFA alloys. The amount of MC increases with increasing the $\mathrm{Nb}$ addition, although the amount and the $\mathrm{Nb}$ dependence of $\mathrm{MC}$ are insensitive to the level of the $\mathrm{Al}$ addition. At $1023 \mathrm{~K}\left(750^{\circ} \mathrm{C}\right)$, on the other hand, B2 and Laves phases become the dominant second phases in the AFA alloys. The fraction of these phases increases with increasing the $\mathrm{Nb}$ addition for a given $\mathrm{Al}$ addition level. $\mathrm{M}_{23} \mathrm{C}_{6}$ appears only with low $\mathrm{Nb}$ additions, and $\mathrm{MC}$ substitutes for $\mathrm{M}_{23} \mathrm{C}_{6}$ by increasing the level of the $\mathrm{Nb}$ addition, which is due in part to holding the carbon addition level ( $\sim 0.1 \mathrm{wt}$ pct) constant in these calculations. Increasing the level of the $\mathrm{Al}$ addition increases the amount of $\mathrm{B} 2$ significantly and stabilizes $\mathrm{M}_{23} \mathrm{C}_{6}$ relative to $\mathrm{MC}$ for a given $\mathrm{Nb}$ level. These calculation results are consistent with the microstructure observation of the alloys after creep-rupture testing at $1023 \mathrm{~K}\left(750{ }^{\circ} \mathrm{C}\right),{ }^{[12]}$ suggesting that the calculation results are reliable. Since the creep properties of the AFA alloys to date relied on precipitate strengthening, the second-phase prediction described above can also be used to develop the other series of AFA alloys, such as the higher $\mathrm{Ni}$ containing or higher $\mathrm{Mn} /$ lower $\mathrm{Ni}$ containing alloys. ${ }^{[13]}$

\section{Microstructure}

Figure 4 shows a typical microstructure of the AFA alloys after solution heat treatment at $1523 \mathrm{~K}\left(1250{ }^{\circ} \mathrm{C}\right)$ (Figure 4(a), scanning electron microscope-backscattered electron image (SEM-BSE)), after aging for 2000 hours at
$1023 \mathrm{~K}\left(750{ }^{\circ} \mathrm{C}\right)$ (Figure 4(b), SEM-BSE), and after creeprupture testing for around 2000 hours at $1023 \mathrm{~K}\left(750^{\circ} \mathrm{C}\right)$ and $100 \mathrm{MPa}$ (Figure 4(c), transmission electron microscope-bright-field image (TEM-BFI)). Note that the alloys in the images are $\mathrm{Fe}-12 \mathrm{Cr}-4 \mathrm{Al}-1 \mathrm{Nb}-0.1 \mathrm{C}$ base (Figures 4(a) and (b)) and Fe-14Cr-2.5Al-0.9Nb-0.08C base (Figure 4(c)). ${ }^{[6,12]}$ The solution heat treatment resulted in $\gamma$-Fe single matrix with a limited amount of coarse MC-type carbides with 1- to $2-\mu \mathrm{m}$ size, consistent with the results of thermodynamic calculations (e.g., Figure 3). The Laves phase of similar shape and size to the coarse MC carbides is also observed in the case of the high ( $>3$ wt pct range) Nb-containing alloys. It should be noted that the solution heat-treated specimens could be cold rolled to more than 90 pct thickness reduction, indicating that the coarse second-phase particles do not degrade room-temperature workability of the alloys. ${ }^{[7]}$

After aging at $1023 \mathrm{~K}\left(750{ }^{\circ} \mathrm{C}\right)$, most of the $\gamma$-Fe matrix and the grain boundary were covered by dense and fine second phases, mainly NiAl-type B2 phase (rodlike particles with dark contrast, $300-\mathrm{nm}$ to $1-\mu \mathrm{m}$ size) and $\mathrm{Fe}_{2}(\mathrm{Mo}, \mathrm{Nb}$ )-type Laves phase (spherical particles with bright contrast in the matrix, less than $500 \mathrm{~nm}$ size), together with the coarse MC (brighter particles near the grain boundary, 1- to $2-\mu \mathrm{m}$ size) that remained from solution heat treatment. The size of the second-phase precipitates remained less than $1 \mu \mathrm{m}$ after 2000 hours exposure at $1023 \mathrm{~K}\left(750{ }^{\circ} \mathrm{C}\right)$, indicating the high thermal stability of the precipitates at this temperature. It is known that the B2 phase precipitate is not effective in improving the high-temperature tensile strength of austenitic stainless steels above $\sim 673 \mathrm{~K}$ $\left(400^{\circ} \mathrm{C}\right) .{ }^{[15,30,31]}$ However, a previous study of AFA alloys suggested that the $\mathrm{B} 2$ phase precipitates may have increased the resistance to creep deformation, possibly 

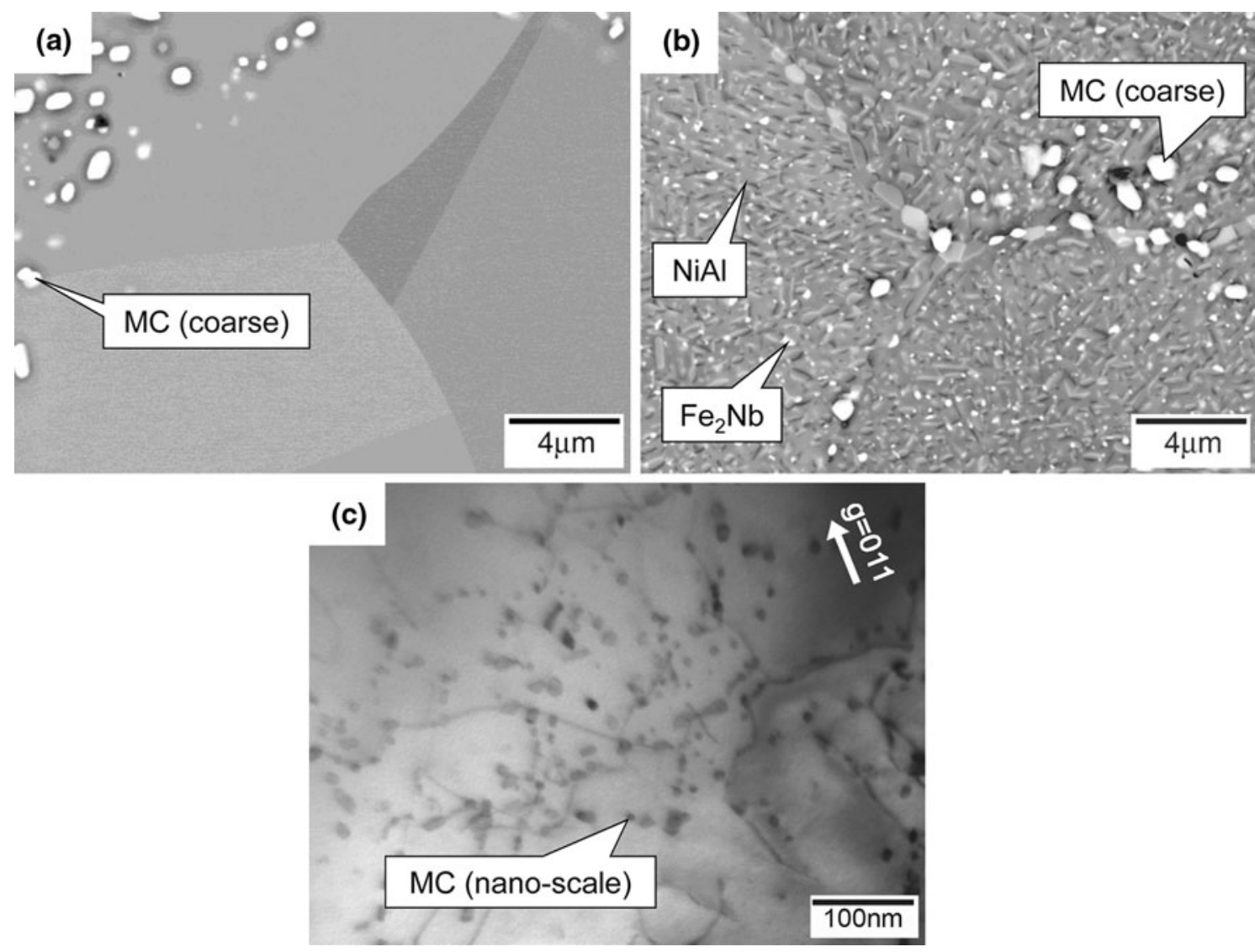

Fig. 4-SEM backscattered electron images and a TEM bright-field image showing a typical microstructure of AFA alloys: $(a)$ after solution heat treatment at $1523 \mathrm{~K}\left(1250{ }^{\circ} \mathrm{C}\right),(b)$ aged at $1023 \mathrm{~K}\left(750{ }^{\circ} \mathrm{C}\right)$ for $2000 \mathrm{~h}\left(\mathrm{C}-1.0\right.$, Ref. 12), and $(c)$ after creep testing at $1023 \mathrm{~K}\left(750{ }^{\circ} \mathrm{C}\right)$ and $100 \mathrm{MPa}$ for $2000 \mathrm{~h}$ (A-0.9, after Refs. 6 and 12).

by affecting dislocation climbing in the matrix or due to the $\mathrm{B} 2$ precipitate resistance to dislocation slicing. ${ }^{[12]} \mathrm{It}$ should also be noted that the creep testing at $1023 \mathrm{~K}$ $\left(750{ }^{\circ} \mathrm{C}\right)$ resulted in finer and denser distribution of these precipitates in the AFA alloys than that in the aged ones, indicating that the creep deformation would be effective to refine the second-phase precipitation.

The main source of the creep resistance was provided from nanoscale MC carbide formation with around 10-nm size, as shown in Figure 4(c), which were effective in pinning dislocations in the $\gamma$-Fe matrix to increase the creep resistance. Cold work (e.g., cold rolling) applied prior to the creep testing was also effective to improve creep properties because the introduced dislocations act as nucleation sites, ${ }^{[32-34]}$ which resulted in almost doubled creep-rupture lives of AFA alloys at $1023 \mathrm{~K}$ $\left(750{ }^{\circ} \mathrm{C}\right) \cdot{ }^{[7,12]}$

\section{MECHANICAL AND OXIDATION PROPERTIES}

\section{A. Creep Properties}

The creep-rupture lives obtained for the most creepresistant AFA alloys thus far under high load/moderate duration conditions (most rupture life data in the 200 to
2000 hour range) are comparable to state-of-art advanced austenitic alloys such as Alloy 709 (Fe-20Cr-25Ni wt pct base) and approach that of the Ni-base Alloy617 (Ni-20Cr-10Co-8Mo base). Figure 5 shows the LarsonMiller parameter (LMP) of the AFA alloys tested at $1023 \mathrm{~K}$ to $1123 \mathrm{~K}\left(750{ }^{\circ} \mathrm{C}\right.$ to $\left.850{ }^{\circ} \mathrm{C}\right)$, together with those of commercially available chromia-forming heatresistant steel alloys, plotted as a function of stress. $^{[5,10,12,35]}$ Data for the $20 \mathrm{wt}$ pet Ni containing alloys spread in the wide range of LMP because of different alloying additions in the range of $\mathrm{Fe}-(12-14) \mathrm{Cr}-$ (2.5-4Al)-(0.2-3.3) Nb-(0.08-0.1)C (wt pet) with small alloying additions, ${ }^{[6,7,12]}$ and most of the data are in the range between Alloy709 and Alloy617. Since the price of $\mathrm{Ni}$ has increased significantly in recent years (and with great volatility) ${ }^{[29]}$ the comparable or even lower levels of Ni content in the AFA alloys compared to advanced austenitic/Ni-base alloys are a further advantage in addition to the superior oxidation resistance of the protective alumina scale. The AFA alloys with $25 \mathrm{wt}$ pct $\mathrm{Ni}$ addition fall among the lower range of creep-rupture lives exhibited by AFA alloys; however, increasing the $\mathrm{Ni}$ content from 20 to $25 \mathrm{wt}$ pct is associated with greatly improved oxidation resistance. ${ }^{[11,14]}$ Further optimization of the creep resistance in light of oxidation resistance is in progress. 
Microstructure characterization as well as considerations of the phase equilibrium reveals that nanoscale MC carbides are the dominant source of creep resistance in the AFA alloy family. ${ }^{[12]}$ Maximizing the amount of $\mathrm{MC}(\mathrm{M}=\mathrm{Nb}, \mathrm{Ti}, \mathrm{V}, \mathrm{Ta}$, etc. $)$ was a major strategy used to achieve high creep resistance in conventional chromia-forming advanced heat-resistant austenitic stainless steels, such as alloy $709,{ }^{[36]}$ by controlling the amount of $\mathrm{M}$ and $\mathrm{C}$ within a stoichiometric ratio. The longest creep-rupture lives of AFA alloys for a given creep test condition (at $1023 \mathrm{~K}\left(750^{\circ} \mathrm{C}\right), 100$ or $170 \mathrm{MPa}$ ) were also observed in alloys with near stoichiometric amounts of $\mathrm{Nb}$ and $\mathrm{C}$ additions ( 0.6 to 1.0 and $0.1 \mathrm{wt}$ pct, respectively). TEM observations reveal that such alloys after creep testing exhibit the highest amounts of nanoscale MC carbides among all of the tested alloys, which is consistent with the thermodynamic calculation results. ${ }^{[12]}$ Therefore, maximizing the amount of nanoscale MC carbides is a key to optimizing creep resistance of the AFA alloys. Since the calculations also predicted very little effect of the $\mathrm{Ni}$

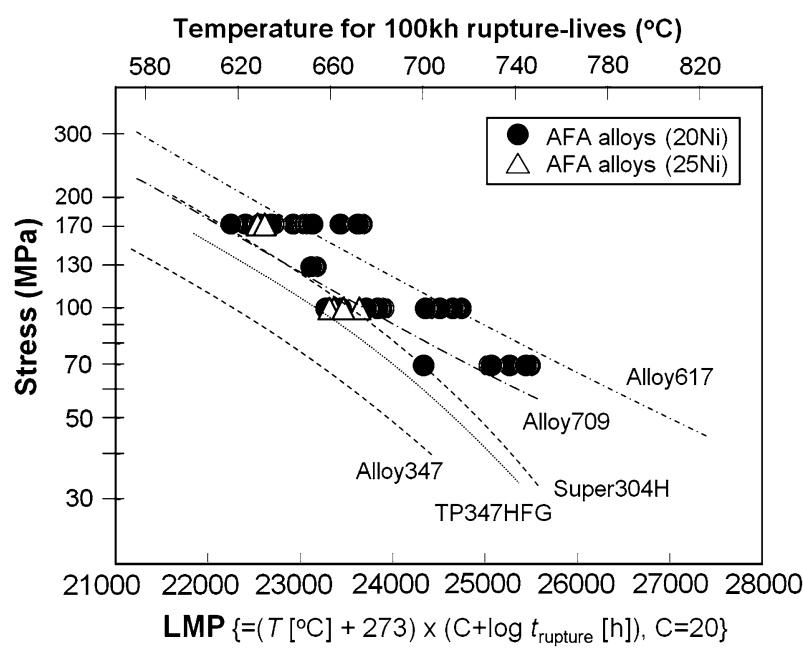

Fig. 5-LMP plot of AFA alloys together with commercially available heat-resistant steels and alloys. ${ }^{[5,10,12,35]}$ addition on the amount of MC carbides, further study is planned to understand why the 25 wt pet Ni AFA alloys developed to date generally exhibit lower creep resistance than those based on $20 \mathrm{wt}$ pct Ni.

\section{B. Tensile Properties}

Table II summarizes tensile properties of selected AFA alloys in the solution heat-treated condition and after aging at $1023 \mathrm{~K}\left(750{ }^{\circ} \mathrm{C}\right)$ for 500 or 2000 hours. $^{[10,15,37]}$ Three different series of the AFA alloys were evaluated, 20Ni-(3-4)Al-(0.6-1.0) Nb base, $25 \mathrm{~N} 4 \mathrm{Al}-1 \mathrm{Nb}$, and $25 \mathrm{Ni}-3.5 \mathrm{Al}-2.5 \mathrm{Nb}$ base alloys. However, little composition dependence effect on the tensile properties was observed. At room temperature, the yield stress and ultimate tensile stress (YS and UTS, respectively), increase and the elongation to fracture decreases after aging. However, the ductility after aging still exhibits more than 10 pct at room temperature. At $1023 \mathrm{~K}$ $\left(750{ }^{\circ} \mathrm{C}\right)$, on the other hand, the YS/UTS as well as the elongation exhibits not much difference before and after aging, indicating a lesser effect of aging on the mechanical properties. This result suggests that the mechanical properties of the materials would not be degraded during long-time operation at elevated temperatures, which is preferable for the high-temperature structural applications. It should be noted that the high-temperature YS and UTS of advanced austenitic stainless steel, such as Alloy 709, are around 200 and $400 \mathrm{MPa}$ at $1023 \mathrm{~K}$ $\left(750{ }^{\circ} \mathrm{C}\right)$, respectively, ${ }^{[36]}$ indicating that the tensile properties of the AFA alloys are comparable to commercially available heat-resistant austenitic stainless steels.

Microstructure characterization reveals that the NiAltype B2 phase precipitates are the main source of strengthening at room temperature in the $20 \mathrm{Ni}-(3-4) \mathrm{Al}-$ $(0.6-1.0) \mathrm{Nb}$ base and $25 \mathrm{Ni}-4 \mathrm{Al}-1 \mathrm{Nb}$ base alloys, ${ }^{[15]}$ which appears after aging at $1023 \mathrm{~K}\left(750^{\circ} \mathrm{C}\right)$ as a dominant second-phase precipitate in $\gamma$-Fe matrix (i.e., Figure 4(b)). On the other hand, the B2 phase precipitates would not strengthen the materials at $1023 \mathrm{~K}$ $\left(750{ }^{\circ} \mathrm{C}\right)$, because the testing temperature is higher than

Table II. Tensile Properties of Selected AFA Alloys ${ }^{[10,15,37]}$

\begin{tabular}{|c|c|c|c|c|c|c|}
\hline AFA alloys & $\mathrm{GS}^{*}(\mu \mathrm{m})$ & $\begin{array}{c}\text { Test Temperature } \mathrm{K} \\
\left({ }^{\circ} \mathrm{C}\right)\end{array}$ & *SA or Aged & YS (MPa) & UTS (MPa) & Elongation (Pct) \\
\hline \multirow[t]{3}{*}{$20 \mathrm{Ni}-(3-4) \mathrm{Al}-(0.6-1) \mathrm{Nb}$ base } & 28 to 55 & $293(20)$ & SA & $\begin{array}{l}237 \text { to } 282 \\
422 \text { to } 434\end{array}$ & 568 to 660 & $\begin{array}{l}41 \text { to } 51 \\
11 \text { to } 18\end{array}$ \\
\hline & & $1023(750)$ & $\mathrm{SA}$ & 201 to 226 & 321 to 373 & 32 to 44 \\
\hline & & & aged & 203 to 205 & 279 to 305 & 31 to 36 \\
\hline \multirow{4}{*}{$25 \mathrm{Ni}-4 \mathrm{Al}-1 \mathrm{Nb}$ base } & 52 & $293(20)$ & SA & 273 & 672 & 57 \\
\hline & & & aged & 457 & 562 & 26 \\
\hline & & $1023(750)$ & SA & 216 & 370 & 31 \\
\hline & & & aged & 213 & 278 & 32 \\
\hline \multirow[t]{4}{*}{$25 \mathrm{Ni}-3.5 \mathrm{Al}-2.5 \mathrm{Nb}$ base } & 62 & $293(20)$ & SA & 269 & 692 & 58 \\
\hline & & & aged & 475 & 941 & 25 \\
\hline & & $1023(750)$ & SA & 232 & 319 & 42 \\
\hline & & & aged & 233 & 328 & 31 \\
\hline
\end{tabular}

${ }^{*}$ GS: average grain size, SA: solution heat treated at $1473 \mathrm{~K}$ to $1523 \mathrm{~K}\left(1200{ }^{\circ} \mathrm{C}\right.$ to $\left.1250{ }^{\circ} \mathrm{C}\right)$, aged: aged for 500 or $2000 \mathrm{~h}$ at $1023 \mathrm{~K}\left(750{ }^{\circ} \mathrm{C}\right)$. 
the ductile-brittle transition temperature of the phase. ${ }^{[15]}$ This could avoid the brittle nature of the intermetallic phase precipitates and, therefore, the AFA alloys after aging, which results in the ductile features of the materials at elevated temperatures. The $25 \mathrm{Ni}-3.5 \mathrm{Al}-$ $2.5 \mathrm{Nb}$ base alloy after aging exhibited a higher amount of $\mathrm{Fe}_{2}(\mathrm{Mo}, \mathrm{Nb})$ Laves phase precipitates than the other alloys because of the high $\mathrm{Nb}$ addition. The mechanical properties of the aged alloy are almost similar to the others at both room and elevated temperatures, indicating that the Laves phase precipitation does not degrade the ductility, as well as the strength, of the AFA alloys at elevated temperatures. ${ }^{[37]}$ These results also prove indirectly that the resistance of creep deformation relies on the dispersions of nanoscale MC carbides as a main source of strengthening because of low expectation of the B2 or Laves phase strengthening effect on the AFA alloys at high temperature. It should be noted that the B2 phase precipitates play an important role for the oxidation resistance, ${ }^{[14]}$ because they act as an $\mathrm{Al}$ reservoir, which provides $\mathrm{Al}$ to maintain the protective $\mathrm{Al}_{2} \mathrm{O}_{3}$ scale on the surface during exposure at elevated temperatures.

\section{Oxidation Resistance}

An unexpected finding in AFA alloys is that oxidation resistance correlates not simply with the level of $\mathrm{Al}$ and $\mathrm{Cr}$ additions, but also with the level of $\mathrm{Nb}$ and $\mathrm{Ni}$ additions. Figure 6 shows plots of the $\mathrm{Al}$ and $\mathrm{Nb}$ contents in AFA alloys relative to alumina scale formation. ${ }^{[10,14]}$ The alloys above the boundary lines exhibit external, protective alumina scale formation (based on 20 to $50 \times 100$ hour cyclic oxidation testing, total $\sim 2000$ to 5000 hours exposure, scale thickness typically on the order of a micron or less) at designated conditions. Below the lines, the alloys show internal oxidation of $\mathrm{Al}$ with $\mathrm{Fe}$ - and $\mathrm{Cr}$-rich oxide nodule formation after a certain number of cycles of oxidation test. The relative amounts of $\mathrm{Al}$ and $\mathrm{Nb}$ needed for the external alumina scale formation in air increase moderately from $1073 \mathrm{~K}$ to $1173 \mathrm{~K}\left(800{ }^{\circ} \mathrm{C}\right.$ to $\left.900{ }^{\circ} \mathrm{C}\right)$ (Figure 6(a)). Increasing the Ni level from 20 to 25 to 26 wt pet significantly decreases the amount of $\mathrm{Nb}$ needed for alumina scale formation at $1173 \mathrm{~K}\left(900{ }^{\circ} \mathrm{C}\right)$ in air, indicating that the $\mathrm{Ni}$ addition is also a key to improving oxidation resistance. In air with 10 vol pet water vapor at $1073 \mathrm{~K}\left(800^{\circ} \mathrm{C}\right)$, on the other hand, much higher $\mathrm{Nb}$ (2.5 to $3 \mathrm{wt} \mathrm{pct}$ ) rather than high $\mathrm{Al}$ is needed for the protective alumina scale formation (Figure 6(b)). Resistance in oxidizing environments containing high concentrations of water vapor is a key issue not only for fossil-fired steam plants, but also for applications ranging from combustion environments in gas turbines and engines to chemical/petrochemical processing to solid oxide fuel cell heat exchangers. It should be noted that virtually all the AFA alloys developed to date show good oxidation resistance at $923 \mathrm{~K}$ to $973 \mathrm{~K}\left(650{ }^{\circ} \mathrm{C}\right.$ to $\left.700{ }^{\circ} \mathrm{C}\right)$ in water vapor conditions, which is the temperature range of interest for near-future advanced fossil-fired steam plants. ${ }^{[1-4]}$

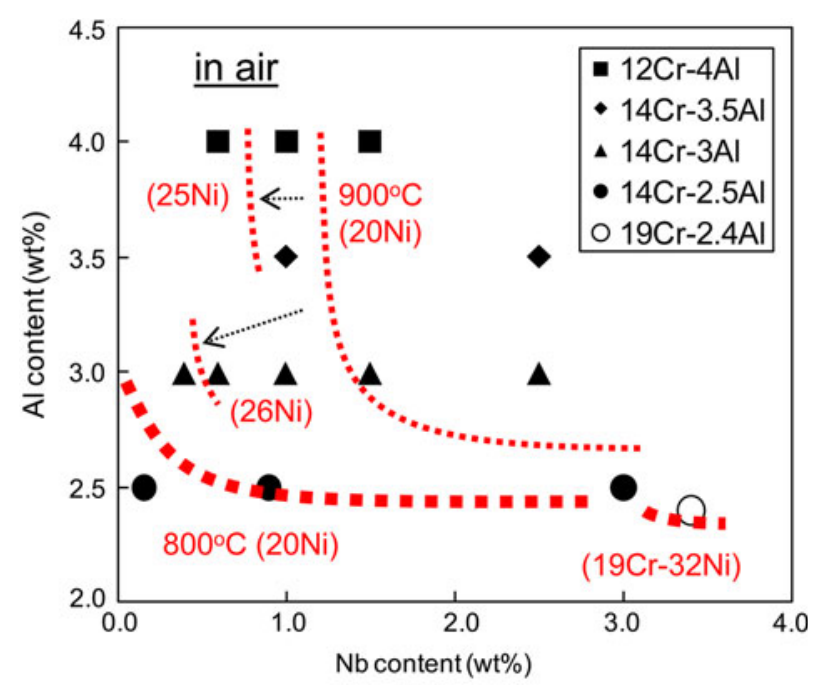

(a)

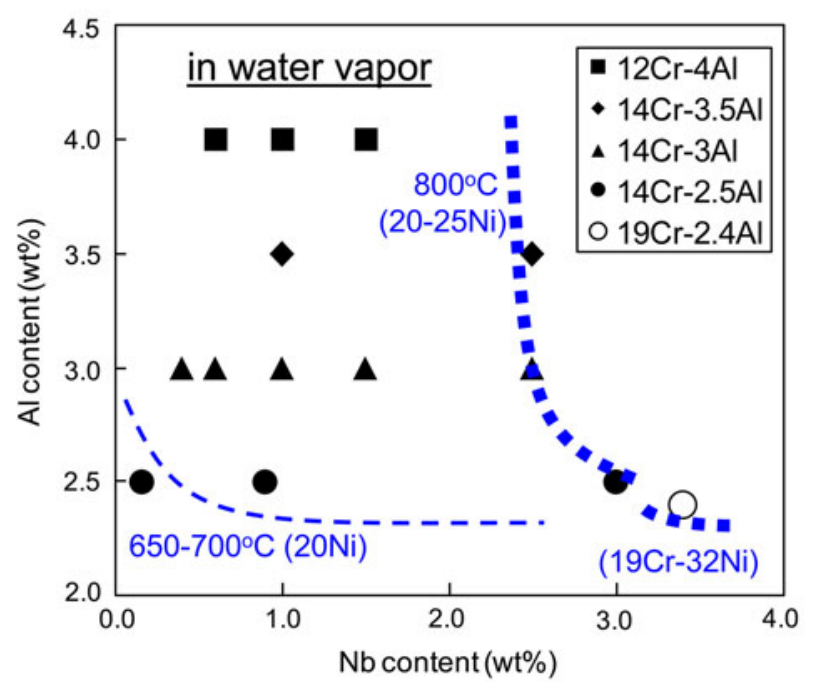

(b)

Fig. 6 - Composition maps of alumina scale formation as a function of $\mathrm{Al}$ and $\mathrm{Nb}$ level in $(a)$ air and $(b)$ air with 10 pct water vapor. Compositions above the boundary lines (estimated) exhibit high oxidation resistance after 2000 to $5000 \mathrm{~h}$ exposure $(20$ to $50 \times 100 \mathrm{~h}$ cyclic oxidation testing) at those conditions due to protective alumina scale formation. ${ }^{[10]}$

The effect of $\mathrm{Nb}$ additions on improving oxidation resistance is explained, in part, by their effects on B2 phase precipitation and the $\mathrm{Cr}$ content in the austenitic matrix. Figure 7 illustrates the effect of $\mathrm{Nb}$ additions on the contents of $\mathrm{Al}, \mathrm{Cr}, \mathrm{Nb}$, and $\mathrm{Mo}$ in the $\gamma$-Fe matrix phase at $1023 \mathrm{~K}\left(750{ }^{\circ} \mathrm{C}\right)$, predicted from thermodynamic calculations. ${ }^{[14]}$ The solution limits of Al decrease slightly with increasing the $\mathrm{Nb}$ additions, and they are insensitive to the Al additions (Figure 7(a)). This is directly correlated with the amount of the B2 phase, as shown in Figure 3(b), indicating that the amount of $\mathrm{B} 2$ precipitates, which act as an Al reservoir, increases with the increasing amounts of $\mathrm{Nb}$ and $\mathrm{Al}$ additions. The $\mathrm{Cr}$ content in the austenitic matrix (Figure 7(b)) also increases significantly with the increasing $\mathrm{Nb}$ addition. The austenite matrix phase with only $\sim 1.5$ to $2 \mathrm{wt}$ pct $\mathrm{Al}$ is dependent on the 


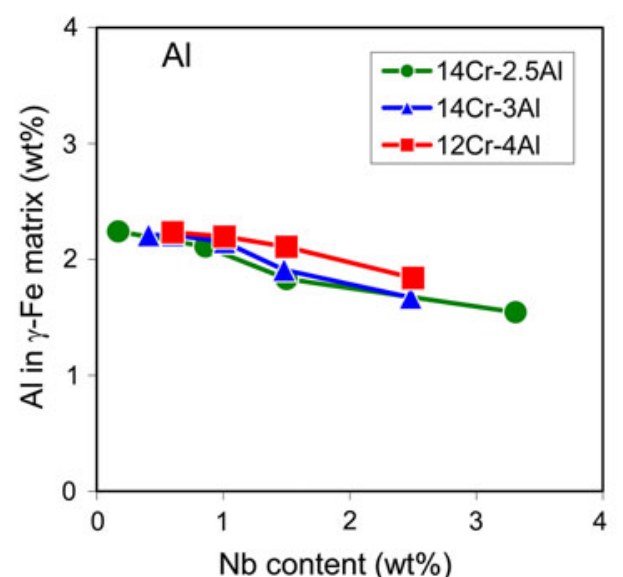

(a)

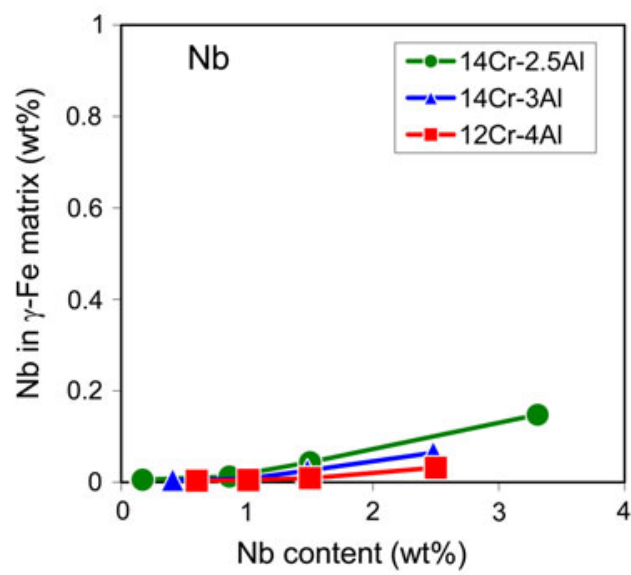

(c)

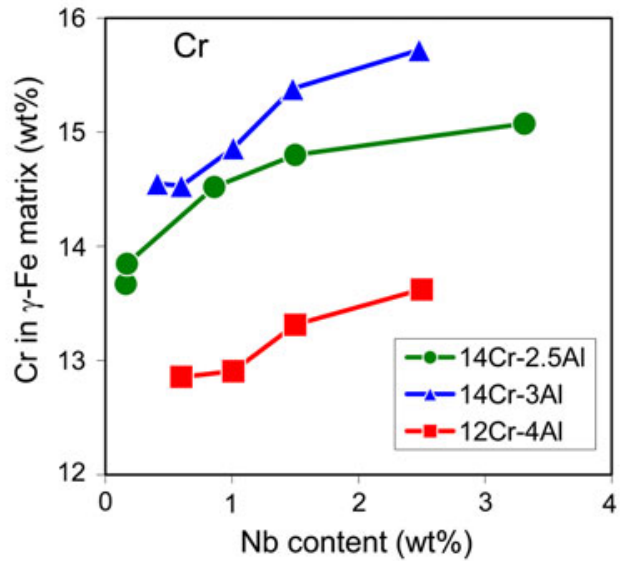

(b)

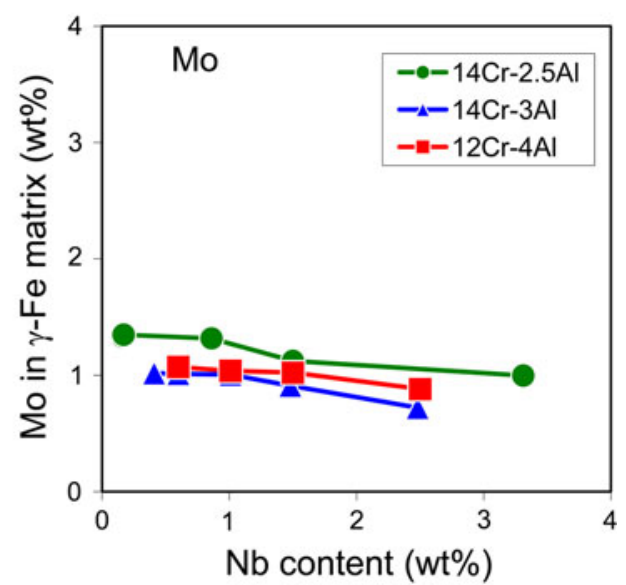

(d)

Fig. 7-Dependence of nominal $\mathrm{Nb}$ contents on the amounts of $\mathrm{Al}, \mathrm{Cr}, \mathrm{Nb}$, and Mo in austenitic matrix of the 20 wt pet $\mathrm{Ni}$ containing AFA alloys at $1023 \mathrm{~K}\left(750{ }^{\circ} \mathrm{C}\right)((a),(b),(c)$, and $(d)$, respectively, from Ref. 14$)$.

beneficial third-element effect of $\mathrm{Cr}^{[28,38]}$ to establish a protective alumina scale, and the higher $\mathrm{Cr}$ contents would be more effective for the stabilizing alumina scale. The $\mathrm{Nb}$ and Mo contents in the matrix (Figures 7(c) and $7(d)$, respectively) are relatively insensitive to the $\mathrm{Nb}$ additions, suggesting that these elements in the matrix would not affect oxidation resistance directly. The excess $\mathrm{Nb}$ and $\mathrm{Mo}$ would decompose to form $\mathrm{NbC}$ and $\mathrm{Fe}_{2}(\mathrm{Mo}, \mathrm{Nb})$-type Laves phases, which increase with the increasing $\mathrm{Nb}$ additions (Figure 3(b)).

The mechanisms behind these trends for oxidation resistance are not completely understood yet and are the subject of ongoing investigation. Oxygen solubility in the alloys is also speculated to be a key factor, with increased $\mathrm{Nb}$ level possibly reducing oxygen solubility, which would favor external alumina scale formation. ${ }^{[5]}$ Given the strong correlation of $\mathrm{Nb}$ level with oxidation resistance in water vapor environments, it is also possible that increasing the level of $\mathrm{Nb}$ increases the number or nature of microstructural sinks for hydrogen species introduced into the alloy from the water vapor. Recent studies of conventional chromia-forming alloys have implicated hydrogen ingress into the alloy from water vapor with an increased tendency for internal oxidation. ${ }^{[39]}$

\section{FUTURE ALLOY DESIGN DIRECTIONS}

\section{A. Mn Substitution for $N i$}

The initial identification of lower-cost, low Ni containing grade of AFA alloy has been successfully demonstrated by using $\mathrm{Mn}$ substitution for $\mathrm{Ni}$, which resulted in almost half the amount of $\mathrm{Ni}$ addition compared to the initial development of AFA alloys (12 vs 20 to 25 pct Ni). ${ }^{[13]}$ The Mn substitution for $\mathrm{Ni}$ would be beneficial for stabilizing the austenitic matrix relative to $\delta$-Fe phase and reducing the raw material cost of the AFA alloys because of the lesser expense of $\mathrm{Mn}$ relative to Ni. ${ }^{[29]}$ Although the effect of the Mn addition on the austenite stabilization becomes stronger by combining with the $\mathrm{N}$ addition, ${ }^{[40]}$ it interferes with mechanical properties (and likely alumina scale formation) because of coarse AIN formation. ${ }^{[41]}$ Therefore, in this grade of AFA alloys, $\mathrm{Cu}$ was added in conjunction with $\mathrm{Mn}$, to further stabilize the austenite phase and contribute to strengthening via $\alpha-\mathrm{Cu}$ precipitates. ${ }^{[35]}$

Thermodynamic calculations together with microstructure analysis of alloys reveal that the composition range of high Mn containing alloys with an austenitic 


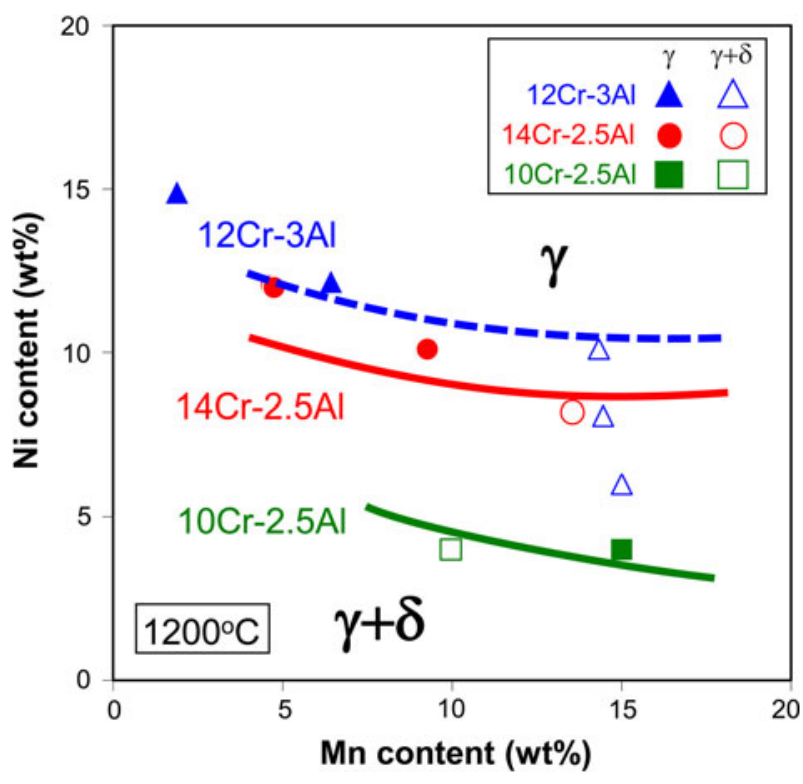

Fig. 8-Ni-Mn phase diagram for $\mathrm{Fe}-\mathrm{Cr}-\mathrm{Al}-\mathrm{Mn}-\mathrm{Ni}-\mathrm{Nb}-\mathrm{Cu}-\mathrm{C}$ base alloys showing estimated phase boundaries between $\gamma$-Fe singlephase and $\gamma-\mathrm{Fe}+\delta$-Fe dual-phase matrix regions at $1473 \mathrm{~K}$ $\left(1200{ }^{\circ} \mathrm{C}\right)$ defined by experimental results combined with thermodynamic calculations. ${ }^{[13]}$

single matrix strongly depends on the $\mathrm{Cr}$ and $\mathrm{Al}$ levels, ${ }^{[13]}$ as shown in Figure 8 . The $\mathrm{Cr}$ addition increases the amount of $\mathrm{Ni}$ required to achieve an austenitic single matrix, and the Al addition shows stronger austenite destabilizing effect than that of the $\mathrm{Cr}$ addition. The alloys based on Fe-14Cr-2.5Al-(5-10)Mn(10-12) Ni-Cu-Nb-C were selected from the phase diagram. The alloys achieved moderate creep strength comparable to chromia-forming Alloy 347 (Fe-18Cr$11 \mathrm{Ni}-\mathrm{Nb}-\mathrm{C}$ base), together with superior oxidation resistance to the Alloy 347 at $923 \mathrm{~K}\left(650^{\circ} \mathrm{C}\right)$ in $10 \mathrm{pct}$ water vapor condition because of the protective alumina scale formation. The alloys with lower $\mathrm{Cr}$ resulted in internal oxidation of $\mathrm{Al}$, and the alloys with higher $\mathrm{Al}$ showed less creep resistance because of $\delta$-Fe formation. This inexpensive AFA alloy grade is a candidate substituting for commercial heat-resistant austenitic stainless steels such as Alloy 347 in the $\sim 823 \mathrm{~K}$ to $923 \mathrm{~K}\left(550{ }^{\circ} \mathrm{C}\right.$ to $\left.650^{\circ} \mathrm{C}\right)$ range, particularly for applications in chemical and petrochemical processing, where high-temperature oxidation and corrosion resistance is a key issue. This low Ni/high Mn AFA alloy grade is not considered a candidate for advanced fossilfired steam plants due to relatively low creep resistance and, from an oxidation standpoint, is estimated to be limited to applications below $\sim 923 \mathrm{~K}\left(650{ }^{\circ} \mathrm{C}\right)$.

\section{B. Alumina-Forming Fe-Base Superalloys}

Expansion of the AFA alloy family to higher performance/higher creep resistance grades is also potentially possible and of great interest for advanced fossil-fired steam plants. For example, $\mathrm{Ni}_{3} \mathrm{Al}$-type $\mathrm{L}_{2}\left(\gamma^{\prime}\right)$ phase precipitates can also be used as a strengthener for Fe-based AFA alloys. Figure 9 shows a TEM-BFI of an

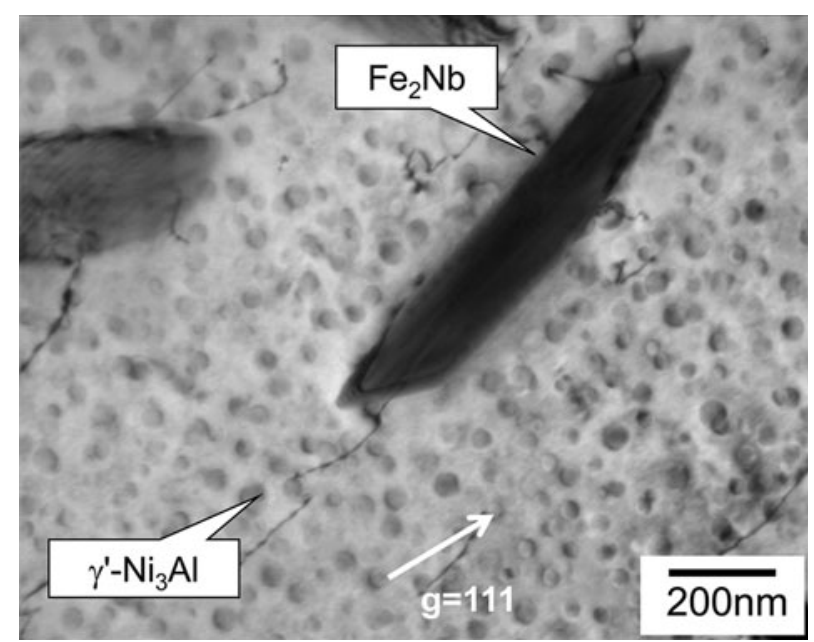

Fig. 9-TEM bright-field image of an AFA alloy based on $\mathrm{Fe}-19 \mathrm{Cr}$ 2.5Al-32Ni-3.3Nb (wt pct) after creep-rupture testing for $500 \mathrm{~h}$ at $1023 \mathrm{~K}\left(750{ }^{\circ} \mathrm{C}\right)$ and $100 \mathrm{MPa}$, showing spherical $\gamma^{\prime}-\mathrm{Ni}_{3} \mathrm{Al}$ precipitates with sizes ranging between 10 and $30 \mathrm{~nm}$ dispersed in an austenite matrix. ${ }^{[9]}$

AFA alloy based on Fe-19Cr-2.5Al-32Ni-3.3Nb after creep-rupture testing for 500 hours at $1023 \mathrm{~K}\left(750{ }^{\circ} \mathrm{C}\right)$ and $100 \mathrm{MPa}$, which exhibits lower creep rate and longer creep-rupture life than those of a similar alloy without $\gamma^{\prime}$ precipitates, ${ }^{[9]}$ although it should be noted that the creep resistance was still significantly lower than that observed by the MC carbide strengthened AFA alloys described in the present work. The microstructure of dense, spherical 30-nm size range $\gamma^{\prime}$ in this exploratory AFA alloy is similar to that reported in the commercial chromia-forming Fe-base superalloy, A286 (Fe-15Cr-25Ni base). Alloy A286 exhibits metastable $\gamma^{\prime}-$ $\mathrm{Ni}_{3}(\mathrm{Al}, \mathrm{Ti})$ phase precipitates due to alloying levels of 2 wt pet Ti and only 0.2 wt pet $\mathrm{Al}$ addition, which has a restriction on the upper-bound temperature limited to $1003 \mathrm{~K}\left(730{ }^{\circ} \mathrm{C}\right)$ because of the formation of brittle, stable $\eta-\mathrm{Ni}_{3} \mathrm{Ti}\left(\mathrm{D}_{19}\right)$ phase. ${ }^{[42]}$ The alloy shown in Figure 9 forms the $\gamma^{\prime}$ precipitates at higher temperature than A286 and has an advantage of protective alumina scale formation. Therefore, this alloy is of interest as a base alloy for a new alumina-forming class of Fe-base superalloy.

\section{CONCLUSIONS}

This article summarized our recent efforts for the development of creep-resistant, alumina-forming austenitic (AFA) stainless steel alloys of interest for a wide range of high-temperature structural applications in aggressive oxidation/corrosion environments, including those encountered in fossil-fired steam plants.

The AFA alloys require a balance of $\mathrm{Al}$ and $\mathrm{Cr}$ additions to achieve an external, protective alumina scale formation at elevated temperatures, while avoiding $\delta$-Fe and $\sigma-\mathrm{FeCr}$ relative to $\gamma$-Fe. High-temperature strength of AFA alloys relies on second-phase precipitates, primarily nanoscale MC-type carbides 
(M: mainly $\mathrm{Nb}$ ) in an austenitic single-phase matrix, although $\mathrm{NiAl}-\mathrm{B} 2$ and $\mathrm{Fe}_{2}(\mathrm{Mo}, \mathrm{Nb})$-Laves precipitates may also contribute. Maximizing the amount of MC carbides can optimize the creep-rupture life of AFA alloys at around $1023 \mathrm{~K}\left(750^{\circ} \mathrm{C}\right)$. The NiAl-B2 phase precipitates also play an important role for the oxidation resistance, because they act as an $\mathrm{Al}$ reservoir for the external protective alumina scale during exposure at elevated temperatures. Higher $\mathrm{Nb}$ levels $(>0.6$ to $1 \mathrm{wt}$ pct) also correlate with improved oxidation resistance, particularly in water vapor environments. A complete mechanistic understanding of the effects of $\mathrm{Nb}$ oxidation has not yet been achieved. Future alloy development directions for the AFA alloy family include both a lower cost, low-Ni/high-Mn grade and a higher performance, Fe-base superalloy AFA grade.

\section{ACKNOWLEDGMENTS}

The authors thank Drs. S. Dryepondt, R.R. Unocic, and P.F. Tortorelli for helpful comments on this manuscript. This research was sponsored by the U.S. Department of Energy (US-DOE), Fossil Energy Advanced Research Materials program, and US-DOE, Office of Energy Efficiency and Renewable Energy, Industrial Technologies Program, under Contract No. DE-AC05-00OR22725 with UT-Batelle, LLC. Part of the research was conducted at the Shared Research Equipment (SHaRE) user facility, which is sponsored at Oak Ridge National Laboratory by the Division of Scientific User Facilities, US-DOE.

\section{REFERENCES}

1. R. Viswanathan and W. Bakker: J. Mater. Eng. Perf., 2001, vol. 10, pp. 81-95.

2. R. Viswanathan and W. Bakker: J. Mater. Eng. Perf., 2001, vol. 10, pp. 96-101.

3. R. Viswanathan, R. Purgert, and P. Rawls: Adv. Mater. Processes, 2008, Aug., pp. 47-49.

4. R. Viswanathan, R. Purgert, and P. Rawls: Adv. Mater. Processes, 2008, Sept., pp. 41-45.

5. M.P. Brady, Y. Yamamoto, M.L. Santella, P.J. Maziasz, B.A. Pint, and C.T. Liu: $J O M, 2008$, vol. 60 (7), pp. 12-18.

6. Y. Yamamoto, M.P. Brady, Z.P. Lu, P.J. Maziasz, C. Liu, B.A. Pint, K.L. More, H.M. Meyer, and E.A. Payzant: Science, 2007, vol. 316 (5823), pp. 433-36.

7. Y. Yamamoto, M.P. Brady, Z.P. Lu, C.T. Liu, M. Takeyama, P.J. Maziasz, and B.A. Pint: Metall. Mater. Trans. A, 2007, vol. 38A, pp. 2737-46.

8. M.P. Brady, Y. Yamamoto, M.L. Santella, and B.A. Pint: Scripta Mater., 2007, vol. 57 (12), pp. 1117-20.

9. Y. Yamamoto, M. Takeyama, Z.P. Lu, C.T. Liu, N.D. Evans, P.J. Maziasz, and M.P. Brady: Intermetallics, 2008, vol. 16 (3), pp. 453-62.

10. Y. Yamamoto, M.P. Brady, M.L. Santella, B.A. Pint, and P.J. Maziasz: Proc. 33rd Int. Techn. Conf. on Coal Utilization \& Fuel Systems, Clearwater, FL, June 1-5, 2008, B.A. Sakkestad, ed., Coal Technology Association, Gaithersburg, MD, 2008.

11. M.P. Brady, Y. Yamamoto, B.A. Pint, M.L. Santella, P.J. Maziasz, and L.R. Walker: Mater. Sci. Forum, 2008, vols. 595598 , pp. $725-32$.
12. Y. Yamamoto, M.L. Santella, M.P. Brady, H. Bei, and P.J. Maziasz: Metall. Mater. Trans. A, 2009, vol. 40A, pp. 1868-80.

13. Y. Yamamoto, M.L. Santella, C.T. Liu, N.D. Evans, P.J. Maziasz, and M.P. Brady: Mater. Sci. Eng. A, 2009, vol. 524 (1-2), pp. 17685.

14. M.P. Brady, Y. Yamamoto, M.L. Santella, and L.R. Walker: Oxid. Met., 2009, vol. 72 (5-6), pp. 311-33.

15. H. Bei, Y. Yamamoto, M.L. Santella, and M.P. Brady: Mater. Sci. Eng. A, 2010, vol. 527, pp. 2079-86.

16. High Temperature Corrosion, P. Kofstad, ed., Elsevier, London, 1988.

17. E.J. Opila: Mater. Sci. Forum, 2004, vols. 461-464 (2), pp. 765-74.

18. B.A. Pint, R. Peraldi, and P.J. Maziasz: Mater. Sci. Forum, 2004, vols. 461-464 (2), pp. 815-22.

19. V. Ramakrishnan, J.A. McGurty, and N. Jayaraman: Oxid. Met., 1988, vol. 30 (3-4), pp. 185-200.

20. T. Fujioka, M. Kinugasa, S. Iizumi, S. Teshima, and I. Shimizu: U.S. Patent 3,989,514, 1976.

21. J.A. McGurty: U.S. Patent 4,086,085, 1978.

22. J.C. Pivin, D. Delaunay, C. Roques-Carmes, A.M. Huntz, and P. Lacombe: Corros. Sci., 1980, vol. 20 (3), pp. 351-73.

23. L. Colombier and J. Hochmann: Stainless and Heat Resisting Steels, St. Martin's Press, New York, NY, 1968.

24. N.V. Bangaru and R.C. Krutenat: J. Vac. Sci. B, 1984, vol. 2 (4), pp. 806-15.

25. I. Kvernes, M. Oliverire, and P. Kofstad: Corros. Sci., 1977, vol. 17 (3), pp. 237-52.

26. Y. Zhang, B.A. Pint, G.W. Garner, K.M. Cooley, and J.A. Haynes: Surf. Coat. Technol., 2004, vols. 188-189, pp. 35-40.

27. Handbook of Ternary Alloy Phase Diagrams, P. Villars, A. Prince, and H. Okamoto, eds., ASM INTERNATIONAL, Materials Park, OH, 1995, pp. 6769-74.

28. F. Stott, G.C. Wood, and J. Stringer: Oxid. Met., 1995, vol. 44 (1-2), pp. 113-45.

29. "MetalPrice.com (Dec. 2009)," http://www.metalprices.com/ index.asp.

30. D. Satyanarayana, G. Malakondaiah, and D. Sarma: Mater. Characterization, 2001, vol. 47, pp. 61-65.

31. D. Satyanarayana, G. Malakondaiah, and D. Sarma: Mater. Sci. Eng. A, 2002, vol. 323, pp. 119-28.

32. P.J. Maziasz: J. Met., 1989, vol. 41, pp. 14-20.

33. R.W. Swindeman, P.J. Maziasz, E. Bolling, and J.F. King: Oak Ridge National Laboratory Report No. ORNL-6629/P1, Oak Ridge National Laboratory, Oak Ridge, TN, 1990.

34. R.W. Swindeman and P.J. Maziasz: Proc. 1st Int. Conf. on HeatResistant Materials, K. Natesan and D.J. Tillack, eds., ASM INTERNATIONAL, Materials Park, OH, 1991, pp. 251-59.

35. P.J. Maziasz, J.P. Shingledecker, and N.D. Evans: 2007 Proc. ASME Pressure Vessels and Piping Conf., 8th Int. Conf. on Creep and Fatigue at Elevated Temperatures, CREEP8, ASME, New York, NY, 2008, pp. 73-80.

36. Quality and Properties of NF709 Austenitic Stainless Steel for Boiler Tubing Applications, Nippon Steel Corporation, Tokyo, 1996.

37. M.P. Brady, J.H. Magee, Y. Yamamoto, P.J. Maziasz, M.L. Santella, B.A. Pint, and H. Bei: Proceedings of Stainless Steel World 2009 Conference \& Expo, Maastricht, The Netherlands, November 10-12, 2009, Stainless Steel World, The Netherlands, 2009.

38. S.W. Guan and W.W. Smeltzer: Oxid. Met., 1994, vol. 42 (5-6), pp. 375-91.

39. E. Essuman, G.H. Meier, J. Zurek, M. Hansel, and W.J. Quadakkers: Oxid. Met., 2008, vol. 69 (3-4), pp. 143-62.

40. R. Franks, W.O. Binder, and L. Thompson: Trans. ASM, 1955, vol. 47 , pp. 231-66.

41. J.P. Shingledecker, P.J. Maziasz, N.D. Evans, and M.J. Pollard: Proc. Symp. Sponsored by Materials Science \& Technology 2005, R.S. Mishra, J.C. Earthman, S.V. Raj, and R. Viswanathan, eds., The Minerals, Metals and Materials Society, Pittsburgh, PA, Sept. 2005, pp. 25-28.

42. H. De Cicco, M.I. Luppo, L.M. Gribaudo, and J. Ovejero-Garcia: Mater. Characterization, 2004, vol. 52, pp. 85-92. 